\title{
How Ageing and Quality of Life is Influenced by Social Relationships: An Exploration of Rural Midlife Women in Ireland
}

\author{
Alison Herbert
}

\begin{abstract}
The aim of this article is to examine and contribute to the existing body of knowledge on gendered rural ageing by exploring, from a lifecourse perspective, the pivotal role of social relationships in shaping the quality of life for rural women at mid-life and beyond. Quality of life is examined in relation to the contributing factor of social relationships, and the article further explores concepts that intersect with social relationships to influence quality of life, including those of place, work, and health. As part of the examination of social relationships, complementary concepts of social inclusion and exclusion, social isolation, and loneliness are also explored. Findings from qualitative interviews with 25 women in rural Ireland aged 45-65 years, together with grounded theory analysis, suggest that the quality of life experienced by rural women at mid-life is primarily influenced by the presence, absence, and quality of social relationships experienced with family, friends, and other members of the community. Although a number of influencing factors contribute to perceived quality of life, meaningful social connectivity takes precedence. In considering life beyond middle-age, rural women envisage social inclusion as playing an increasingly vital role in shaping their ageing and their quality of life.
\end{abstract}

KEY WORDS rural ageing; mid-life women; quality of life; social inclusion; social exclusion; lifecourse; social relationships

\section{Introduction}

While there has been a growing "turn" towards lifecourse studies in the social sciences, particularly in ageing and human development, (Alwin 2012; Elder 1998; Settersten and Mayer 1997), little is known on the lifecourse features of social relationships and their gendered nature (Arber, Davidson and Ginn 2003), particularly at mid-life (Biggs 1999). Ageing is, however, a gendered issue. Muhlbauer (2007), for example, speaks of an expansive or contractive view adopted by women at mid-life in which they either embrace a sense of growth and opportunity towards future lifecourse experiences, or develop a sense of vulnerability and loss. These divergent perspectives adopted at mid-life may well have the capacity to influence future ageing and quality of life and exposure to forms of social inclusion or exclusion. This article explores the crucial role played by relationships

Sociální studia / Social Studies 1/2018. Pp. 45-64. ISSN 1214-813X. 
on quality of life (Lachman, Teshale and Agrigoroaei 2015), and of how the quality of these relationships may impact upon forms of social inclusion and exclusion. Relatively little is known about the ways in which ageing and social exclusion intersect across the entire lifecourse, particularly at mid-life, considered to be a pivotal stage in influencing future ageing (Lachman et al. 2015). Existing work, with some notable exceptions, also typically ignores the spatial context of rural relationships (O'Shea, Walsh and Scharf 2012) at mid-life (Thurston and Meadows 2004), and of how the context of rurality and social relationships intersect to form multiple pathways that may lead to forms of social exclusion.

\section{Aims}

This article aims to explore social relationships and women's ageing at the critically recognised mid-lifecourse stage, rather than solely within old age, as is the norm within much social gerontology research. This is of significance as existing literature suggests connections between lived experiences at mid-life and those in older age (Arber and Ginn 2004; Arnold 2005; Dittmann-Kohli and Jopp 2007; Higgs et al. 2005; Lachman et al. 2015a). Crucial mid-lifecourse transitions, such as divorce, widowhood and retirement, particularly within the context of a recessionary economy as experienced by Ireland from the period of 2008 to its current post-crisis state (OECD 2018), may significantly influence the ageing process. Pointedly, Ireland's period of austerity has been framed in inter-generational terms, suggesting that the economy's negative impact is disproportionately greater among the younger and middle-aged generations (Walsh, Carney and Ní Léime 2015). This study contributes to our understanding of gendered mid-life rural ageing from a lifecourse perspective and extends existing knowledge by examining the multiple pathways that have the capacity to influence perspectives on the ageing process both at mid-life and in older age when women may be more vulnerable to forms of social exclusion.

This paper is organised as follows: the introduction is followed by aims of the study, which is followed by a section on quality of life and the gender dimension. This is followed by a section addressing social exclusion, isolation and loneliness: a lifecourse perspective. This is followed in turn by a section addressing the spatial/place-related dimension. Methodology and findings is ended by sections covering discussion, conclusions and future directions.

\section{Quality of life and the gender dimension}

Whilst some issues and concepts around the mid-life stage of the lifecourse appear to be gender-neutral, embracing both men and women, their application may sometimes be a matter of degree. For example, mid-life may be a time of review for both men and women, but for women, its application may be more critical. This is a time when women tend to assess lived experiences and behaviours from earlier lifecourse stages, and consider trajectories into older age (Dittmann-Kohli and Jopp 2007; Wiggs 2010), particularly from a corporeal perspective in which the ageing body comes to prominence (Woodspring 2016). 
Biggs (1997, 2005) writes extensively on the mid-life stage, examining ageism, identity management, and successful ageing, amongst other matters, and whilst some of his work applies to men and women, a large tract is directed towards mid-life women, whom he perceives as being particularly vulnerable to combined sexism and ageism. Whilst certain traits may be shared at mid-life between both men and women, the male trajectory across the lifecourse is often quite separate from that of the female with regard to work, finance, health, and social relationships. This point is critical; historically, women live longer than men do, and thus have a longer time period during which to experience forms of social exclusion. Perspectives held at mid-life on growing older may have implications in later life (Hendricks 2012; Higgs et al. 2005), and individuals who experience exclusion in mid-life may be especially vulnerable to forms of exclusion in later life (Kneale 2012; Walsh, O'Shea and Scharf 2012). Such forms of mid-life exclusion may encompass poor quality relationships and lack of support from family and community, low levels of income from precarious employment, declining health, and low place attachment as personal needs change in response to lived experiences.

\section{Social relationships and quality of life}

Positive social connections with others represent a recognised human need, improving health and well-being. This is of particular relevance to older persons, both men and women, whose social networks - that is, the structural components of social relationships - may become diminished in terms of both quantity, for example through relocation or death, and quality with the passage of time. A lack of meaningful social relationships, and perceived loneliness in particular, has been linked in a number of studies to physical and mental health issues (Santini et al. 2016) and to social exclusion (Gray 2009; Muckenhuber, Stronegger and Freidl 2013). Negative health issues include premature mortality, cardiovascular disease, depression, and dementia (Holt-Lunstad and Smith 2012; Holt-Lunstad et al. 2015).

While the term loneliness is meaningful to most people, it can also be a vague concept with multiple meanings (Cattan et al. 2005). Furthermore, while loneliness and social isolation are related concepts, both of which may negatively impact on quality of life in older age, it is evident that not all isolated people are lonely and not all lonely people are socially isolated. A meta-analytic review by Holt-Lunstad et al. (2015) examines the two concepts of loneliness and social isolation separately and as possible correlates, searching for insights into possible independent pathways that may guide intervention efforts. The study argues that there is no difference between objective and subjective measures of social isolation when predicting mortality and finds that higher survival rates are experienced by those with better social connections. Holt-Lunstad et al. (2015) argue that both social isolation and loneliness, although quite distinct concepts, must be considered jointly in efforts to mitigate risk of mortality, as increasing social contact alone may not mitigate loneliness. However social isolation and loneliness are viewed, it seems prudent, as much of the literature argues, that these two concepts should be considered as legitimate public health concerns. This is particularly relevant to Ireland, where The Irish Longitudinal Study of Ageing (TILDA) reports higher levels of perceived loneliness amongst women than men (Walsh et al. 2015: 
122). Holt-Lunstad et al. (2015) suggest that the mortality risk of loneliness is greater than that associated with obesity, and concur with recent research predicting loneliness to reach epidemic proportions by 2030 unless policy interventions are implemented. Although living alone can offer advantages, physical health does not appear to be one of these.

Crucially, studies on the role of social relationships and the mental health of older people have shown distinct gender differences, with social support from extended sources found to be particularly important to women. If this is the case, then longevity, along with an increasing prevalence of "solo" living brought about by a single, child-free, divorced, separated or widowed status, may put women at particular risk of loneliness and poorer health in older age. The quality of relationships with children is argued to be of greater significance to women than to men (Santini et al. 2016), and women also appear to seek support from a wider circle of friends than men do (Rose 2007). This may partially compensate for poor partnership relationships, a factor which has been more strongly linked to poor mental health amongst men than women. If relationships with children and friends are more crucial to the well-being of women, and spousal relationships more important to the well-being of men, it may be that gender-specific interventions are the most appropriate in addressing perceived loneliness in later life.

\section{Social exclusion, isolation and loneliness: a lifecourse perspective}

In operationalising social exclusion from social relations, reference is typically made to measurements of social isolation and loneliness. This approach draws a useful distinction between social isolation on the one hand, representing an objective measure of the frequency of social contacts, and loneliness on the other, a subjective judgement of the perceived gap between the quantity and quality of actual and desired social relationships (Scharf 2015; Victor and Scharf 2005). Social exclusion has been conceptualised as a lack of or denial of resources, rights, goods and services, and as the inability to participate in socio-economic, cultural or political relationships and activities normally available to the majority of people in society (Levitas 2012; Scharf 2015; Walsh, Scharf and Keating 2016). Integral components of social exclusion include the socio-cultural context in determining what passes as "normal" in society, and internal or external agency. Social exclusion is multi-dimensional and dynamic in nature: individuals move in and out of forms of exclusion as their circumstances change with their progress across the lifecourse (Scharf 2015). In social gerontology, key domains that contribute to an understanding of social exclusion in later life centre around exclusion from material resources, civic activities, formal services, along with the dimensions that this article is focusing on: those of social relations and community/neighbourhood (Scharf 2015: 118). Social inclusion, which Scharf and Keating (2012) consider to be under-theorised as a concept in work on ageing, is generally taken to be an appropriate alternative to social exclusion, and a valuable, aspirational goal for societies (Scharf and Keating 2012).

Individual agency and choice, along with divergence in lived experiences across the lifecourse, may radically dispose individuals, who may otherwise appear to mirror one another, towards either social inclusion or exclusion. Such divergence in the experiences of exclusion may be partly explained through resilience theories, which show that individuals 
who navigate adversity, such as loss of a loved one or diminishing social networks, whilst maintaining high levels of functioning across a number of domains, demonstrate stronger resilience. It is argued that public policy interventions aimed at building social capital (that is, potential benefits derived from social relationships) amongst an ageing population can help to foster resilience, a greater sense of well-being, and perceptions of social inclusion (Cosco, Howse and Brayne 2017).

In order for society to "aspire to" improved social inclusion in older age, it is essential to explore the nuances around gendered rural mid-life ageing and examine the ways in which lived experiences can create social inequalities. Rather than viewing social exclusion and, by extension, social inclusion as binaries, research points to the need to identify their contributory intersecting domains, including those of exclusion from meaningful social relations along with territorial or community exclusion (Grenier and Guberman 2009; Scharf, Phillipson and Smith 2005).

Whilst the concept of social exclusion remains a contested notion with multiple definitions (Walsh et al. 2012; Walsh et al. 2016), it is nonetheless generally held to be widening and deepening over time, despite policy measures aimed at reducing exclusion. It is contended that one reason for this may be the relatively narrow focus adopted by many European states that views productivity and extended working life as a primary strategy in addressing social integration and promoting social inclusion. This approach to ageing policy tends to ignore the complex multidimensional pathways available to accumulate social capital (Scharf et al. 2001), and overlooks forms of exclusion in later life that go beyond employment. Indicators of exclusion that affect ageing adults include: age discrimination, limited financial resources and access to essential services, health constraints, and place of residence, particularly rural place (Walsh et al. 2012).

\section{A spatial/place-related dimension to quality of life}

Identifying the diverse pathways and influencing factors of social exclusion at the mid-life stage, particularly for rural women, whose lifecourse experiences may be quite different from those of urban women, may assist in making more effective policy interventions designed to enhance quality of life in older age. A wide body of literature recognises spatial features as locations for and drivers of social exclusion through a range of social, cultural, and economic characteristics (Walsh et al. 2012). From a spatial perspective, social exclusion may be experienced by ageing adults as a lack of place attachment, a multi-dimensional construct that may reflect aesthetic, emotional, historical, or socio-economic components. The fundamental personal relationship with place has been found to constantly evolve alongside the symbolic meaning of place, and is dependent upon the changing demographic and cultural elements that define place (Walsh 2015: 83). Such cultural elements may evolve over time, resulting in older rural women experiencing different degrees of attachment to place across the lifecourse.

In Ireland, studies illustrate how the physical, spatial, and structural characteristics of place are connected to older people's social and economic participation within their local communities (Walsh 2015: 81). Key lifecourse events that have been identified as posing 
a possible threat to social inclusion include: divorce or separation, widowhood, retirement from work, change of residence, the assumption of caring duties, and the loss of physical mobility or mental acuity (Victor and Scharf 2005). Individual vulnerabilities may be due to socio-economic and spatial inequalities and lifecourse events that reduce the supportive potential of their social networks (Hennessy, Means and Burholt 2014; Scharf, Walsh and O'Shea 2016).

One body of literature argues that older single or childless women, or those living alone, particularly if ageing within a rural context, have amongst the lowest levels of social capital accrued, and are especially vulnerable to social exclusion brought about by limited informal social supports (Scharf et al. 2016). This is to assume, however, that adult children or proximal family are willing to take on caring roles in relation to ageing parents. Those older persons without family support may perhaps avoid the risks associated with social exclusion if they can draw on other forms of social capital accrued over the lifecourse, such as filial and non-filial friendships, and some research argues that friends play a significant role in augmenting quality of life amongst older women (Santini et al. 2016).

The contributory pathways over the lifecourse that may lead to social exclusion in later life are as heterogeneous as the individuals themselves (Little and Austin 1996). For example, rural women may feel that their areas are socio-economically-politically neglected in favour of urban areas. They may feel that they have outgrown their rural areas, which were considered adequate whilst rearing children in perceived rural safety, but now offer little cultural capital at mid-life. Diminishing rural health, transport (Hennessy et al. 2014), and social services; a reduced reliance on religion (Gill, Minton and Myers 2015); and a changing rural landscape due to in-migration and rising ethnic diversity may be sufficient to increase feelings of fragmentation and reduced attachment to place (Rice and Steel 2001).

Whilst social exclusion may occur within both urban and rural contexts, loneliness has been found to be more prevalent in Ireland's rural communities (Walsh et al. 2015). While rural living presents a number of perceived advantages, including low density living, lower levels of crime and cleaner environs, a wide body of literature (Buffel, Phillipson and Scharf 2013; Smith 2009; Walsh et al. 2016) indicates that rural communities generally do not fare well compared to urban areas regarding the distribution of social and economic resources, particularly in the areas of health and social support, public transport and infrastructure, and employment (Brereton et al. 2011; Edmondson and Scharf 2015; Mahon 2005; Phillipson and Scharf 2005; Scharf et al. 2016; Walsh et al. 2012). Such inequalities as these become heightened during periods of state fiscal austerity or economic downturn, such as that experienced in Ireland from 2008 to its current post-crisis state (OECD 2018). Although Ireland may now be considered out of its recessionary period, many areas of the country, particularly rural areas, have witnessed few improvements (Walsh et al. 2015).

Economic inequalities in rural areas may particularly disadvantage older women, who may already face lower levels of autonomy and agency. Older women may face ageism within the workplace, preventing them from accessing employment (Carvalho Wilks and Neto 2013; Isopahkala-Bouret 2015; Tang 2000; Walker et al. 2007), low access to independent financial resources, including pensions (Duvvury et al. 2012; Ní Léime 2017), or on-going chronic health issues accrued at earlier lifecourse stages (Thurston and Meadows 
2003). Older rural women, particularly those living alone, may also experience reduced opportunities to physically connect with others, due to personal mobility issues, or virtually (Beneito-Montagut, Cassian-Yde and Begueria 2018), through limited rural communications technology (Hennessy et al. 2014). They may also be more negatively affected by lower car ownership than men (Shergold, Parkhurst and Musselwhite 2012), as well as public transport difficulties that do not meet the lifestyle needs of older rural women (Hennessy et al. 2014). All of these factors pose an increased risk of exposure to forms of social exclusion and have the capacity to influence the quality of life and ageing experienced by older rural women.

\section{Methodology}

The methodological approach chosen for this analysis was informed by constructivist grounded theory (CGT), as developed by Charmaz (2006). This is a research paradigm that utilises abductive reasoning, denies the existence of an objective reality, and asserts realities as multiple social constructions of the mind (Charmaz 2006; Ward, Hoare and Gott 2015). Although theory does not always follow from data that have been analysed using a constructivist grounded theory approach, validity, rather than the ability to replicate, is essential. Charmaz (2006) argues that only constructivist grounded theory allows the researcher to become a co-author of the research participant's story. Thus, the methodological research process chosen was one capable of validation through the reflection of data within its various contexts and meanings.

In this qualitative study, primary data were collected over an 18-month period in one-to-one interviews with a diverse, theoretically-guided sample of 25 women aged 45-65 years in rural Connemara, Ireland. In the interests of obtaining rich data, a diversity of participants from different socio-economic, spatial, and ethnic backgrounds was sought. The central research question - What are the perspectives on ageing of mid-life women in rural Ireland? - led to the use of constructivist grounded theory as a research methodology, and the semi-structured interview as a method of data collection. This methodological approach lent itself to the exploratory nature of the research question, allowing participants to freely discuss topics and issues of importance to them at mid-life. Thus, the narrative content was primarily participant led and supported by the researcher.

Recruitment of participants was achieved through personal networks, by contacting key stakeholders, by snowball sampling, and by utilising print and broadcast media to raise awareness. Sampling took place over three timelines: an initial pilot phase of three participants tested the interview technique and the symbolic-interactionist approach to questioning, as well as considering data. Symbolic interactionism derives from a pragmatism that assumes that people construct self, society, and reality through interaction. Thus, interviewer-participant interaction pivoted on the dynamic relationship between the narrative and the meaning participants attached to their actions. This was followed by phase two, during which ten new participants were recruited who helped to fill conceptual gaps left after the pilot phase. These ten participants ranged in marital status, in spatial location, and in socio-economic background. Phase three of the sampling of 12 more participants took place after a six-month period during which further conceptual gaps were considered which had arisen from data gathered during phase two. 
Participants were selected on the conceptual basis that they might add something different to data already collected. After each participant interview, memos and the constant comparison of transcript data allowed for the identification of gaps in knowledge, and the identification of those with a precarious status who may be at risk from some forms of social exclusion. Thus, participants with an intellectual disability were recruited, along with in-migrants, those who were single, childless, or living alone, and those living in remote, more poorly serviced rural areas. This process continued until it was felt that the saturation point of properties that could form categories had been reached within the research sample.

Data analysis of participant transcripts was carried out by coding in an iterative fashion (Charmaz 2006). This entailed the constant comparison of codes both within and between transcripts in order to uncover emerging theory. Transcripts were analysed to explain both content and context, examining not just what was said, but what was sensed through keen observation and interaction. Data analysis was also informed by reference to extensive field-notes and memos. Open codes, using gerunds, were the first step employed to describe participants' words. This was followed by focused coding and theoretical coding. Focused codes are more abstract and conceptualised, representing a synthesis of first-level codes. Theoretical coding allowed for the development of categories and helped move towards possible substantive theory. This reflexive and flexible approach to analysis allowed for the constant comparison of data, codes, concepts, patterns, and gaps until it became clear that the properties of each category had become saturated. This cleared the way for the emergence of a grounded theory that found perspectives on ageing to be influenced by perceived quality of life and in turn by the quality of social relationships, work, health, and place.

The region of Connemara in the West of Ireland was chosen as the research area for a number of reasons, including ease of access. Being in close proximity to Galway City, some $80 \mathrm{~km}$ away, Connemara comprises 38,500 persons (CSO 2016) spread over $1,800 \mathrm{~km}^{2}$, giving it a low population density of almost 17 per $\mathrm{km}^{2}$. Some 5,500 mid-life women, aged 45-65 years, live in Connemara. Clifden town, the "capital" of Connemara, has a population of just over 2,000 persons, which is higher than the definition of "rural" in Ireland as settlements under 1,500 persons (CSO 2016). This figure is down $18 \%$ from the previous census five years earlier. The population of Clifden's surrounding rural area has also decreased by around $10 \%$, currently standing at fewer than 9,000 persons. Clifden is connected to Galway City and its population of around 80,000 persons by a regular daily bus service; however, connectivity by bus to other parts of Connemara is much more infrequent. There is no train service or airport in Connemara. Only a few islands are part of the Connemara region and all are linked to the mainland by regular ferry services. On the fringe of Connemara, the largest of the three Aran islands, Inis Mór, comprising 760 inhabitants (CSO 2016), is connected to the mainland by a ferry and an air service. The drive by road from Galway City to the connecting ferry port or airport is around one hour, and thus all islands are considered relatively well connected to the mainland.

Connemara is considered to be rural, but the question of how we define rural for policy purposes and in relation to people rather than landscape or place has not been fully resolved in Ireland. This study describes participants as residing in a range of rural settings, including remote, dispersed, village, small town, and island. For reasons of clarity these terms were adapted from the population model relating to Scotland (Government 2012), a similarly-sized 
country. In Ireland, some definitions of rural relate to population density whilst others relate to proximal distance from urban development. Yet, how we define rural matters, as it impacts on policy. Ireland is, however, commonly agreed to be the most rural of all EU countries in terms of both population and land area, suggesting that policy relating to rural Ireland is largely relevant to all-Ireland. Thus, rural residents, however defined, have arguably at the very least the same needs for employment, healthcare, education and transport as the rest of the population.

In keeping with the nature of qualitative research, ethical considerations underpinned the entire research process of this study, particularly during data planning, data collection, and data analysis. These points were outlined to the university's ethics committee and ethical approval was granted. Within the participants' narratives on social relationships, a number of participants alluded to the concepts of social inclusion and social exclusion and ultimately provided mixed insights: some participants felt socially included within their communities, whilst others felt excluded. These diverse findings are now addressed.

\section{Findings}

Table 1: Demographic table

\begin{tabular}{|c|c|c|c|c|c|c|c|}
\hline $\begin{array}{l}\text { PEN } \\
\text { NAME }\end{array}$ & AGE & PLACE* & OCCUPATION & EDUCATION & $\begin{array}{l}\text { MARITAL } \\
\text { STATUS }\end{array}$ & $\begin{array}{l}\text { No. } \\
\text { CHILDREN }\end{array}$ & $\begin{array}{l}\text { INDIGENOUS (I)/ } \\
\text { IN-MIGRANT (M) }\end{array}$ \\
\hline Aíne & 52 & Island & Casual & $2^{\text {nd }}$ level & Single & 0 & I \\
\hline Betty & 61 & Small town & Unemployed & $4^{\text {th }}$ level & Single & 0 & M \\
\hline Carole & 51 & Near village & Self-employed & $2^{\text {nd }}$ level & Partner & 0 & I \\
\hline Denise & 57 & Dispersed & Self-employed & $3^{\text {rd }}$ level & Single & 0 & M \\
\hline Hilary & 61 & Village & Full-time & $2^{\text {nd }}$ level & Married & 4 & I \\
\hline Jane & 54 & Village & Unemployed & $2^{\text {nd }}$ level & Married & 3 & M \\
\hline Lelia & 62 & Dispersed & Self-employed & $2^{\text {nd }}$ level & Married & 3 & M \\
\hline May & 65 & Dispersed & Unemployed & $2^{\text {nd }}$ level & Widowed & 6 & I \\
\hline Mhari & 46 & Near village & Part-time & $3^{\text {rd }}$ level & Married & 2 & I \\
\hline Morag & 53 & Near village & Unemployed & 1st level & Single & 0 & I \\
\hline Maebh & 53 & Dispersed & Full-time & $4^{\text {th }}$ level & Married & 0 & M \\
\hline Penny & 59 & Small town & Part-time & $2^{\text {nd }}$ level & Married & 3 & M \\
\hline Sally & 64 & Dispersed & Unemployed & $1^{\text {st }}$ level & Single & 0 & I \\
\hline Síle & 61 & Dispersed & Self-employed & $3^{\text {rd }}$ level & Married & 3 & M \\
\hline
\end{tabular}

Note: * Small town: fewer than 1,500 persons; Dispersed: 'one-off' housing.

\section{Social relationships and quality of life}

Above all other factors, the quality of social relationships had the capacity to influence perceived quality of life and influence feelings of social inclusion or exclusion. No participants reported being entirely satisfied with their relationships across the lifecourse or at mid-life, but their ability to create sufficient levels of connectivity and to foster resilience 
against relationship deficits was perceived as being of the utmost importance in preventing social exclusion in older age.

Mhari's two adult children had left home, leaving her alone with her husband. Experiencing on-going ill health as a result of a virus, 46 year-old Mhari was forced to switch to part-time work, and also reported missing the presence of her children at home, particularly one son with whom she enjoyed a special relationship. Compounding these work and health factors was Mhari's inability to live the full social life she once did, participating in many local activities. She was also experiencing an increasingly poor relationship with her husband, whom she felt was of little emotional support to her. As a consequence, Mhari felt very low place attachment, feeling little in common with her partner and local community, and wanted to move. Her husband, however, was content in their location. At mid-life Mhari had already begun to feel socially excluded:

He [husband] doesn't deal well with crises. I would see him leaning more $100 \%$ on me, even when I am broken. If I was to burst out crying for no reason it would freak him out completely. I've seen the look on his face and it's one of complete horror, even now. He has no clue as to how to handle it, so I would definitely try and deal with it myself or go to my family or friends. I'd leave [here] for an excuse, an idea, a plane ticket. Anything. I'm more attached to people than places. Like more than $99 \%$ of my friends were not born and raised here, and we automatically seem to be on the same wavelength. But people like my husband who was born and raised and lives here, would be definitely on a completely different wavelength all the time. (Mhari, 46 years, near small town)

It may be that if Mhari regains her full health and is once more able to fully participate in community activities that she would feel less socially isolated. However, if she is unable to return to full-time work and continues to experience a fragmented relationship with her husband, then she may continue to feel excluded from her community.

The importance of social relationships in creating social inclusion is further illustrated by two participants who act as carers for their mothers. Both are in-migrants to Connemara, and joined local community organisations as a way of building social capital and becoming more embedded in their new communities:

Because we have no family it was hard to get to know people, so I decided to join everything. A group of us set up the local credit union, and I joined the flower club and the golf club. It was a good way of getting to meet and know people in a new town. We love it now here and wouldn't move. (Kathy, 58 years, village)

Carole, also a carer to her mother, undertook extensive voluntary community work to help cope with the stress of caring duties and a difficult relationship with her partner:

I think if I hadn't got involved in all this, there was a time not that long ago, this time last year, I was shutting down, and I couldn't take an awful lot more. I'd had it up to here, I was on the verge. But through [this community organisation] I've met a wonderful friend and she's amazing, and pushes me, making me believe in myself. (Carole, 51 years, dispersed area) 


\section{Social relationships and health}

Health and social relationships show strong intersections. Physical or mental ill health, particularly amongst those with limited financial resources to secure private health care, may pose a risk of causing social exclusion in older age. However, this may also be the case for healthy participants whose partners' health is impaired. Two participants had adopted informal caring duties for their husbands, which participants felt somewhat restricted their personal freedom. One participant, Maebh, worked full-time; the other, Penny, undertook casual part-time work. Both participants reported feeling stressed by their caring duties and fearful of what the future may hold if they themselves became ill and unable to work or care for their partners. Whilst one participant undertook daily physical exercise to help reduce her stress, Penny took part in social activities and used her GP and friends as confidantes to help her through the mental stress of caring duties:

I do have a lot of stress sometimes, but I don't let it get to me. I would actually go up to the bedroom and have a good cry for myself. Get it out, get over it, and I'd talk to people, my friends, if I was having a really bad day. That helps. It takes a lot for me to talk to someone about it, but I do, and I know that when I do I will feel better afterwards. I have a very good neighbour and a good friend, and actually I talk to the doctor about it, too. (Penny, 59 years, small town)

\section{Social relationships and work}

Work promoted a sense of inclusion in the lives of almost every participant, providing a separate identity to that within the family. Work also provided the opportunity to connect with social relationships outside of the family. Twenty of the 25 participants were in some kind of employment: self-employment, part-time, or full-time salaried within the public or private sectors. Work proved to be crucial for the social inclusion of two participants, Morag and Susan, who had intellectual disabilities and attended a "work-orientated" day-centre. Each lived with a sibling, Morag on the edge of a village, and Susan in a remote rural area. Susan's remote location precluded her from ancillary transport, meaning she could only attend her work centre one day a week, putting her at additional risk of social exclusion. It would likely be impossible for these mid-life women to live alone in later life, should their personal circumstances change. If they find themselves with no guardian or carer, it is possible that they could be taken into institutional care, putting them at further risk of social exclusion from regular community activities.

One participant, Betty, undertook voluntary community work to compensate for her inability to secure work after returning from working abroad for most of her adult life. Betty already felt isolated and lonely at mid-life, living in a new area for the past two years, and struggling to find a fulfilling purpose to compensate for being unable to work as a teacher - her profession and her passion. This situation was in contrast to her busy and fulfilling life abroad as a teacher and missionary. Betty had worked all over the world with her mission but was now finding it difficult to adjust to a life she felt was unproductive, and relied heavily on her faith to sustain her. Living alone, albeit in a small town, and having a low source of income, Betty may well be at risk of social exclusion from her community as she ages further: 
I'd prefer to be working until as long as I could keep going. On the Missions we work up till we are about 80 if we have good health, sound in mind and body. I'm hoping I will be of some service for another 20 years or so anyway. I have a joy for life with the volunteer work and get up every day and even be a small bit of service, I'm still giving of myself. (Betty, 61 years, small town)

It is noteworthy that some of those in employment also expressed feelings of social isolation. Maebh loved her profession of teaching, but not her new school, which she found overwhelming and stressful. In addition to acting as primary carer for her husband, Maebh expressed feelings of uncertainty over her future financial position, and of her physical ability to cope alone with her workload. With no proximal family members living in the area, and no time to travel to meet with friends, Maebh expressed fears around her quality of life in older age:

I'm imagining now in September when I go back to school that I'll have to get someone in for a couple of hours each day [to care for my husband], and it's all financial stress. I didn't join the pension till late. I suppose it was very stupid, but my reasons were so silly, but I could never see myself in my twenties being old. My mother and most of her family died quite young, so I thought the chances of me getting to 65 were so slim. So, I didn't give it much thought, and when I did join I am doing back pay on it, so the longer I work the better it will be in pension terms. (Maebh, 53 years, dispersed area)

\section{Social relationships and place}

This empirical study took place within an Irish rural context, which proved to be pivotal in influencing attitudes on ageing and quality of life from the perspective of place attachment. Some participants felt low levels of place attachment at mid-life and, although their reasons differed, all perceived place to be diminishing their quality of life. Such participants may have enjoyed high place attachment and feelings of social inclusion at earlier stages of the adult lifecourse when rearing children or being fully occupied by employment. In later life, perhaps living alone or with no meaningful work, the ties that bound these participants to their personal place no longer existed, leading at best to feelings of social isolation and a reduced sense of well-being, and at worst to feelings of social exclusion from their community and a perceived poorer quality of life. Critically important, place attachment is a complex concept, which has been found to intersect with social relationships.

One participant, Síle, enjoyed high place attachment throughout earlier stages of the lifecourse when she and her husband ran a hospitality business from home, whilst raising their children. At mid-life, with her children gone, business in decline, and dealing with some personal health issues, Síle felt excluded from her rather inaccessible rural community, which offered no cultural pursuits. At odds with her husband on the issue of leaving the area, Síle did not express optimism for her future, and would appear to be somewhat at risk from social exclusion, should she continue to live in her location.

There's never been a sense of attachment to the local community [but] I felt it more as I got older, not isolated, as I have good friends, and some of the neighbours are very good, [but] as we get older we are so far from anything. There is nothing in our village that I can relate to, no book club 
or anything, [only in a town] that's $80 \mathrm{~km}$ away. When the kids were small [it was different], but now there is no reason for me to go out most days. Now I just go into the village on a Saturday to pick up the newspaper. (Síle, 61 years, dispersed area)

Conversely, a few participants had moved from feelings of isolation and low place attachment at a pre-mid-lifecourse stage to now feeling socially integrated and highly attached at mid-life. This change in place attachment from low to high was often due to the formation of social connections and a strengthened sense of "belonging" (Smith 2009), as well as to a growing appreciation of the aesthetics of place:

At first, I was dreadfully homesick and I have never been back to England since. I was so homesick that I was afraid I'd stay if I went back. [Now, I'm very attached to here]. I didn't realise how attached I was, until we were thinking of selling up to get money for the children, and then we looked around at what we have, a paradise plot by the sea and it's got everything, a lovely garden, with flowers and vegetables and it's easy to access, so we decided to stay put. It would have been stupid to leave. (Jane, 54 years, village)

The interconnections between social relationships, place, work, and health on quality of life This study showed high intersections between social relationships, place, work, health and quality of life. Personal loss evoked strong feelings of loneliness and isolation in two participants, May and Áine, both of whom had experienced the untimely death of adult sons. May also had to deal with the death of her husband, some siblings, and close friends. Both felt that their health was poor, and in May's case chronically poor. May had been unemployed for a number of years, whilst Áine engaged in some casual work. Both felt very much alone. Participant narrative from both women made it clear that each had lost her sense of purpose in life, something all participants considered to be vital to well-being and a good quality of life.

The participants' lives were complex and no one factor can be attributed as having a causal effect, but it is notable that both women lived in dispersed rural areas where public transport was rare, and neither drove a car. Whilst neither participant was bereft of social relationships - one lived with a brother, the other had adult children regularly dropping by both felt completely alone and socially isolated. The older of the two women, 65-year-old May, had been made redundant some years earlier and acted as a part-time carer for her elderly father who lived with a sibling. Enduring ongoing chronic ill health and depression, feeling unable to work, seeing no work available, feeling geographically distant, losing close friends and family members, living mostly alone, and being financially constrained may all prove to be risk factors for her social exclusion in the years ahead:

I do [feel like a failure]. Because I could be happy looking at the trees and everything, and yet I feel this sense of, maybe it's loss, not failure, and I feel a sadness now in myself for my loss. The loss of my physical self, and I'm kind of disconnected from a lot of things. I am so afraid of the passing years, and fear I suppose is my biggest thing. I'm so afraid of it that I'm doing nothing about it, I'd think it's all going so fast, what is the point. Nothing worthwhile now. I don't feel fulfilled. And I don't know how much longer I have, none of us knows. I'm not making the best of what I have and it's bothering me, it is. (May, 65 years, dispersed area) 
The younger of the two women, 52-year-old Áine, was an island-dweller who had a partner on the mainland. Despite having some meaningful social relationships with this partner and her brother, her sense of pointlessness and feelings of isolation may also put her at risk of social exclusion in later life. Áine attributed her poor health at mid-life directly to the loss of her closest relationship - that of her son.

On considering later life: "Well now, there's a plan A and a plan B. If I keep going the way I am now, I think I'll die slowly before I'm 65. Plan B, I could be very lively, a great 65 -year-old, really active". (Áine, 52 years, island-dweller)

\section{Discussion}

Interconnecting pathways between social relationships and quality of life

Findings from this empirical study indicate that the concepts of social relationships and place, along with their multiple influencing factors, such as work and health, are instrumental in contributing to forms of social inclusion, exclusion, and quality of life. Whilst no factor on its own may dominate perceptions of quality of life, the interconnections between influencing factors do have the capacity to lead to feelings of social inclusion or social isolation. Findings from this study ranged from those who felt isolated and at odds with almost everything in their mid-lives - from the nature of their work, from where they lived, from who they lived with, even from their own ageing bodies - to those who appeared to feel completely included within their communities and their families.

Specifically, feelings of social isolation amongst this study's participants were connected to such factors as controlling partners, unfulfilling work, and dissonance with place. Some participants found themselves in unexpected roles at mid-life, such as that of carer, causing feelings of frustration and social isolation. Some participants displayed resilience by adopting coping strategies, such as physical exercise, to deal with the changes that mid-life can bring; others felt unable to do so. For most participants, nurturing positive social relationships was a natural remedy, and may ultimately prove to be the panacea that will protect them most against forms of social exclusion in later life.

Of the majority of participants who did not claim or appear to be at risk of social exclusion at mid-life, it is worth taking a more focused look at their lived experiences and lifecourse trajectories. Strongly forged social relationships with either family or friends proved to be an over-arching factor for those expressing feelings of social inclusion, as did high place attachment, fulfilling work, and a strong sense of life purpose. To illustrate: Denise, whilst single, childless, and living alone as an in-migrant in her rather remote location, expressed high place attachment. Place was perceived as integral to her work as a visual artist, and Denise had developed a strong work ethos and an extended work network to compensate for her lack of proximal family and friends. Whilst Denise had a full work life and high place attachment, she did express concern over the hazards of living alone, including having a serious fall whilst gardening her extensive grounds, and not having proximal help. She also expressed concern over taking on a mortgage at mid-life and not being able to generate sufficient income to sustain herself in older age. 
Lelia, an organic farmer and in-migrant living in a remote rural area, reported a strong social and working relationship with her husband, a strong life purpose, and above all, a passion for their shared religious interests. These factors, she hoped, would cushion her against deficits in health and income in older age, but they could also be insufficient.

Only two participants reported being in well-paid employment, few had private health insurance, and few reported any kind of sizable savings. Thus, it would appear unlikely that most participants would be in a position to buy private health care in later life and may need to rely on close relationships for help. No participant wanted her son, daughter or partner to care for her needs in place in later life should she become dependent, and most feared institutional care. In addition, many participants lived in dispersed or remote areas, and should they lose the ability to drive in later life, they may be further disadvantaged.

Ireland's recent economic recession was associated with higher male unemployment, particularly amongst those involved in construction. A consequence of this can be seen in the number of mid-life women in Connemara who are the sole or principal wage-earner within the household. Hilary was an example of one such woman who worked as a carer and whose unemployed husband and three unemployed adult children were all being supported by her income and state benefits. Hilary enjoyed her work and did not want to retire, but there may come a time when, Hilary feels compelled to retire, a situation that Hilary herself states would seriously reduce her sense of well-being.

A combination of influencing factors, such as diminished physical health, lack of financial resources, spatial inequality through rural location, and unemployment, may well put a number of participants who are coping well at mid-life at risk of social exclusion in older age. A number of the participants in this study had relatively minor ongoing health issues, including muscular-skeletal problems; a few others reported mild depression. At mid-life, all participants reported being able to cope well with health issues, but all expressed concern over health in older age, when they may not be able to work and earn their own income, when they may have to rely on a precarious state pension to survive, when they may not be able to drive (Davey 2007), or when they may suffer from increased dependence and reduced autonomy. In all of these outcomes, it is difficult to see, without gendered interventionist measures at mid-life, how such women will maintain positive feelings of social inclusion enjoyed at mid-life into older age.

\section{Conclusions / future directions}

The aim of this article is to extend our understanding of the role played by social relationships in shaping quality of life and has done so by exploring gendered mid-life rural ageing from a lifecourse perspective, both at mid-life and in older age when women may be more vulnerable to forms of social exclusion.

The 25 participants in this study were socio-economically and geographically diverse in nature. Within the age range of 45-65 years both congruence and incongruence existed amongst participants; those in the early stages of mid-life sometimes held different perspectives from those at the later stages. For instance, those in earlier mid-life tended to worry less about work and health than did those in later mid-life. Pearlman (1993: 112) highlights mid-life 
Table 2: Descriptors of social exclusion amongst mid-life rural women

\begin{tabular}{|l|l|l|l|}
\hline Social Relationships & Place & Work & Health \\
\hline Poor family support & Geographical isolation & Ageism in workplace & $\begin{array}{l}\text { Diminishing physical/ } \\
\text { mental ability }\end{array}$ \\
\hline Loneliness \& isolation & Poor public transport & Low income levels & Institutional care \\
\hline $\begin{array}{l}\text { Poor community } \\
\text { networks }\end{array}$ & Poor IT/broadband & $\begin{array}{l}\text { Absence of private } \\
\text { pensions }\end{array}$ & $\begin{array}{l}\text { Absence of private } \\
\text { healthcare }\end{array}$ \\
\hline Widowhood/divorce/loss & Low attachment & $\begin{array}{l}\text { Forced retirement/ } \\
\text { redundancy }\end{array}$ & $\begin{array}{l}\text { Absence of medical } \\
\text { services }\end{array}$ \\
\hline Living alone & Inability to drive & $\begin{array}{l}\text { Short-term, casual } \\
\text { contracts }\end{array}$ & \\
\hline Acting as carer & $\begin{array}{l}\text { Lack of social/ cultural } \\
\text { amenities }\end{array}$ & Unemployment & \\
\hline No children & & & \\
\hline
\end{tabular}

diversity, stating that socio-economic conditions, including marriage, widowhood, separation, divorce, childbearing, work, and gender, all influence women's choices and lived experiences. Thus, mid-life women's lives can be appreciated in full only when studied within these complex social realities, and their interactions are considered. Perspectives held at mid-life have formed over the lifecourse from long before the participants reached middle age. What this suggests is that policy directives to help deal with the risks of social exclusion must be put in place as early in the adult lifecourse as possible. Historically, public policy has focused primarily on the young and the old and ignored the middle, but this middle has now expanded with longevity. In fact, those in mid-life constitute a sizeable and growing demographic in most developed countries. In Ireland, mid-life women currently represent $22 \%$ of the national population, a figure that is predicted to increase steadily towards a peak of $26 \%$ in 2041 (CSO 2016).

There is a central role for policy to address forms of disadvantage that reduce the quality of life of many older adults (Scharf 2015). Regarding women, gender-sensitive, rural interventions and investments may help to minimise emerging risks of social exclusion at mid-life and beyond. These include initiatives and opportunities that can promote training and employment to enhance financial autonomy (Whiston et al. 2015), and enhanced health and well-being services to safeguard the physical and mental self (Conder, Mirfin-Veitch and Gates 2015). Given the high influence of social relationships and sense of place, interventionist measures that help older rural women connect in diverse ways with their communities would be particularly welcome. Such measures may include: new approaches to the provision of public and private transport (Wang et al. 2015); enhanced access to Broadband and communications technologies used to enhance social relationships (Beneito-Montagut et al. 2018); and the maintenance of social and cultural amenities, all of which may help to improve the formation of social networks (Degnen 2016).

Individually and collectively, such interventions can positively influence the multiple domains that contribute to quality of life in later life, and allow for innovations in policies that some contend are currently skewed towards social exclusion amongst single parents, young people, and low labour market participation (Walsh et al. 2016). If we can learn from 
the diverse experiences of mid-life rural women, we are in a stronger position to evaluate the impact of ageing and the risk of social exclusion in later life. It is from this understanding that policymakers can then proactively address the issues around risk and help ensure a good quality of life for rural women in older age when they may be at their most vulnerable.

\section{References}

ALWIN, Duane F. 2012. "Integrating Varieties of Life Course Concepts." The Journals of Gerontology B 67(2): 206-220.

ARBER, Sara, Kate. DAVIDSON and Jay GINN. 2003. Gender and Ageing: Changing Roles and Relationships. Philadelphia: OUP.

BENEITO-MONTAGUT, Roser, Nizaia CASSIAN-YDE and Arantza BEGUERIA. 2018. "What Do We Know About the Relationship between Internet-Mediated Interaction and Social Isolation and Loneliness in Later Life?" Quality in Ageing and Older Adults 19(1): 14-30.

BIGGS, Simon. 1997. "Choosing Not to Be Old? Masks, Bodies and Identity Management in Later Life." Ageing \& Society 17: 553-570.

BIGGS, Simon. 1999. The Mature Imagination: Dynamics of Identity in Midlife and Beyond. Buckingham, Philadelphia: OUP.

BIGGS, Simon. 2005. "Beyond Appearances: Perspectives on Identity in Later Life and Some Implications for Method." The Journals of Gerontology B 60(3): 118-128.

BRERETON, Finbarr, Craig BULLOCK, Peter J. CLINCH and Mark SCOTT. 2011. "Rural Change and Individual Well-Being: The Case of Ireland and Rural Quality of Life." European Urban and Regional Studies 18(2): 203-227.

BUFFEL, Tine, Chris PHILLIPSON and Thomas SCHARF. 2013. "Experiences of Neighbourhood Exclusion and Inclusion among Older People Living in Deprived Inner-City Areas in Belgium and England." Ageing \& Society 33(1): 89-109.

CARVALHO WILKS, Daniela and Felix NETO. 2013. "Workplace Well-Being, Gender and Age: Examining the 'Double Jeopardy' Effect.” Social Indicators Research 114(3): 875-890.

CATTAN, Mima, Martin WHITE, John BOND and Alison LEARMOUTH. 2005. "Preventing Social Isolation and Loneliness among Older People: A Systematic Review of Health Promotion Interventions." Ageing \& Society 25(1): 41-67.

CHARMAZ, Kathy. 2006. Constructing Grounded Theory: A Practical Guide through Qualitative Analysis. London: SAGE.

CONDER, Ann, Brigit Frances MIRFIN-VEITCH and Sue GATES. 2015. "Risk and Resilience Factors in the Mental Health and Well-Being of Women with Intellectual Disability." Journal of Applied Research in Intellectual Disabilities 28(6): 572-583.

COSCO, Theodore D., Kenneth HOWSE and Carol BRAYNE. 2017. "Healthy Ageing, Resilience and Wellbeing." Epidemiology and Psychiatric Sciences 26(6): 579-583.

CSO. 2016, "Census." Cork, Ireland. Retrieved September 28, 2018 (www.cso.ie).

DAVEY, Judith A. 2007. “Older People and Transport: Coping without a Car.” Ageing and Society 27(1): 49-65.

DEGNEN, Cathrine. 2016. "Socialising Place Attachment: Place, Social Memory and Embodied Affordances." Ageing and Society 36(8): 1-23.

DITTMANN-KOHLI, Freya and Daniela JOPP. 2007. "Self and Life Management: Wholesome Knowledge for the Third Age.” Pp. 268-295 in Ageing in Society, edited by John BOND, Sheila M. PEACE, Freya DITTMANN-KOHLI and Gerben WESTERHOF. London: SAGE. 
DUVVURY, Nata, Áine NÍ LÉIME, Aoife CALLAN, Linda PRICE and Mark SIMPSON. 2012. Older Women Workers'Access to Pensions: Vulnerabilities, Perspectives and Strategies. Galway, Belfast: NUI Galway; Queen's University Belfast.

EDMONDSON, Ricca and Thomas SCHARF. 2015. "Rural and Urban Ageing." Pp. 412-419 in Routledge Handbook of Cultural Gerontology, edited by Julia TWIGG and Wendy MARTIN. New York: Routledge.

ELDER, Glen H. Jr. 1998. "The Life Course as Developmental Theory.” Child Development 69(1): 1-12.

GILL, Carmen Sue, Casey Barrio MINTON and Jane MYERS. 2015. "Poor, Rural Women: Spirituality, Religion, and Wellness across the Life Span." Adultspan 14(2) 66-76.

GOVERNMENT, Scottish. O. o. t. C. Statistician, G. I. S. A. T. (GI-SAT) and R. a. E. S. a. A. S. Division. 2012. "Scottish Government Urban/Rural Classification." Edinburgh.

GRAY, Anne. 2009. "The Social Capital of Older People.” Ageing \& Society 29(1): 5-31.

GRENIER, Amanda M. and Nancy GUBERMAN. 2009. "Creating and Sustaining Disadvantage: The Relevance of a Social Exclusion Framework." Heath and Social Care in the Community 17(2): $116-124$.

HENDRICKS, Jon. 2012. “Considering Life Course Concepts.” The Journals of Gerontology B 67(2): 226-231.

HENNESSY, Catherine, Robin MEANS and Vanessa BURHOLT, eds. 2014. Countryside Connections: Older People, Community and Place in Rural Britain. Bristol: Policy Press.

HIGGS, Paul, Martin HYDE, Sara ARBER, David BLANE, Elizabeth BREEZE, James NAZROO and Dick WIGGINS. 2005. "Dimensions of the Inequalities in Quality of Life in Older Age." In Understanding Quality of Life in Old Age, edited by Alan WALKER. London: Open University Press.

HOLT-LUNSTAD, Julianne and Timothy B. SMITH. 2012. "Social Relationships and Mortality.” Social and Personality Psychology Compass 6(1): 41-53.

HOLT-LUNSTAD, Julianne, Timothy B. SMITH, Mark BAKER, Tyler HARRIS and David STEPHENSON. 2015. "Loneliness and Social Isolation as Risk Factors for Mortality: A Meta-Analytic Review." Association for Psychological Science 10(2): 227-237.

ISOPAHKALA-BOURET, Ulpukka. 2015. "Graduation at 50+: Contested Efforts to Construct 'Third Age' Identities and Negotiate Cultural Age Stereotypes.” Journal of Aging Studies 35: 1-9.

KNEALE, Dylan. 2012. Is Social Exclusion Still Important for Older People? London: International Longevity Centre UK.

LACHMAN, Margie E., Salom TESHALE and Stefan AGRIGOROAEI. 2015. "Midlife as a Pivotal Period in the Life Course: Balancing Growth and Decline at the Crossroads of Youth and Old Age." International Journal of Behavioral Development 39(1): 20-31.

LEVITAS, Ruth. 2012. "The Just's Umbrella: Austerity and the Big Society in Coalition Policy and Beyond." Critical Social Policy 32(3): 320-342.

LITTLE, Jo and Patricia AUSTIN. 1996. "Women and the Rural Idyll.” Journal of Rural Studies 12(2): $101-111$.

MAHON, Marie. 2005. "Articulating Perceptions of Rural and Urban - The Use of Semantic Scales." Irish Geography 38(2): 192-208.

MUCKENHUBER, Johanna, Willubald J. STRONEGGER and Wolfgang FREIDL. 2013. "Social Capital Affects the Health of Older People More Strongly Than That of Younger People." Ageing \& Society 33(5): 853-870.

MUHLBAUER, Varda. 2007. "The Well-Being and Quality of Life of Women over 50: A Gendered-Age Perspective.” Pp. 95-111 in Women over 50: Psychological Perspectives, edited by Varda MUHLBAUER and Joan C. CHRISLER. New York: Springer.

NÍ LÉIME, Áine. 2017. "Older Women Public Sector Workers in Ireland: Decisions About Retirement Timing." Journal of Women and Aging 29(5): 392-404. 
O'SHEA, Eamon, Kieran WALSH and Thomas SCHARF. 2012. "Exploring Community Perceptions of the Relationship between Age and Social Exclusion in Rural Areas." Quality in Ageing and Older Adults 13(1): 16-26.

OECD. 2018. The Organisation for Economic Co-Operation and Development Economic Surveys, Ireland. Dublin: OECD.

PEARLMAN, Sarah F. 1993. "Late Mid-Life Astonishment: Disruptions to Identity and Self-Esteem." Women and Therapy: A Feminist Quarterly 14(1/2) 1-12.

PHILLIPSON, Chris and Thomas SCHARF. 2005. "Rural and Urban Perspectives on Growing Old: Developing a New Research Agenda.” European Journal of Ageing 2(2): 67-75.

RICE, Tom W. and Brent STEEL. 2001. "White Ethnic Diversity and Community Attachment in Small Iowa Towns.” Social Science Quarterly 82(2) 397-407.

ROSE, Suzanna M. 2007. “Enjoying the Returns: Women's Friendships after 50.” Pp. 112-130 in Women over 50: Psychological Perspectives, edited by Varda MUHLBAUER and Joan C. CHRISLER. New York: Springer.

SANTINI, Ziggi Ivan, Katherine Leigh FIORI, Joanne FEENEY, Stefano TYROVOLAS, Josep Maria HARO and Ai KOYANAGI. 2016. "Social Relationships, Loneliness, and Mental Health among Older Men and Women in Ireland: A Prospective Community-Based Study." Journal of Affective Disorders 204: 59-69.

SCHARF, Thomas. 2015. "Between Inclusion and Exclusion in Later Life." Pp. 113-130 in Ageing through Austerity, edited by Kieran WALSH, Gemma M. CARNEY, and Áine NÍ LÉIME. Bristol, UK: Policy Press.

SCHARF, Thomas and Norah C. KEATING, eds. 2012. From Exclusion to Inclusion in Old Age: A Global Challenge. Bristol, UK: Policy Press.

SCHARF, Thomas, Chris PHILLIPSON, Paul KINGSTON and Allison E. SMITH. 2001. "Social Exclusion and Older People: Exploring the Connections." Education and Ageing 16(3): 303-320.

SCHARF, Thomas, Chris PHILLIPSON and Allison E. SMITH. 2005. "Social Exclusion of Older People in Deprived Urban Communities of England." European Journal of Ageing 2(2): 76-87.

SCHARF, Thomas, Kieran WALSH and Eamon O'SHEA. 2016. “Ageing in Rural Places.” Pp. 50-61 in Routledge International Handbook of Rural Studies, edited by Mark SHUCKSMITH and David L. BROWN. New York: Routledge.

SETTERSTEN, Richard A. and Karl Ulrich MAYER. 1997. "The Measurement of Age, Age Structuring, and the Life Course.” Annual Review Sociology 23: 233-261.

SHERGOLD, Ian, Graham PARKHURST and Charles MUSSELWHITE. 2012. "Rural Car Dependence: An Emerging Barrier to Community Activity for Older People." Transportation Planning and Technology, 35(1): 69-85.

SMITH, Allison E. 2009. Ageing in Urban Neighbourhoods: Place Attachment and Social Exclusion. Bristol, UK: Policy Press.

TANG, Kwong-Leung. 2000. "Ageism and Sexism at Work: The Middle-Aged Women of Hong Kong." Gender, Technology and Development 4(2): 225-253.

THURSTON, Wilfreda E. and Lynn M. MEADOWS. 2003. "Rurality and Health: Perspectives of Mid-Life Women." The International Electronic Journal of Rural and Remote Health Research, Education, Practice and Policy 3(3): 219. (http://rrh.deakin.edu.au).

THURSTON, Wilfreda E. and Lynn M. MEADOWS. 2004. "Embodied Minds, Restless Spirits: Mid-Life Rural Women Speak of Their Health." Women and Health 39(3): 97-112.

VICTOR, Christina and Thomas SCHARF. 2005. "Social Isolation and Loneliness." In Understanding Quality of Life in Old Age, edited by Alan WALKER. London: Open University Press.

WALKER, Helen, Diane GRANT, Mark MEADOWS and Ian COOK. 2007. "Women's Experiences and Perceptions of Age Discrimination in Employment: Implications for Research and Policy." Social Policy and Society 6(1): 37-48. 
WALSH, Kieran. 2015. "Interrogating the 'Age-Friendly Community' in Austerity: Myths, Realities and the Influence of Place Context." Pp. 79-96 in Ageing through Austerity, edited by Kieran WALSH, Gemma M. CARNEY and Áine NÍ LÉIME. Bristol, UK: Policy Press.

WALSH, Kieran, Gemma M. CARNEY and Áine NÍ LÉIME, eds. 2015. Ageing through Austerity. Bristol, UK: Policy Press.

WALSH, Kieran, Eamon O'SHEA and Thomas SCHARF. 2012. "Social Exclusion and Ageing in Diverse Rural Communities: Findings of a Cross-Border Study in Ireland and Northern Ireland." HARC Research Network. Irish Centre for Social Gerontology, National University of Ireland Galway: Irish Centre for Social Gerontology, NUIG.

WALSH, Kieran, Thomas SCHARF and Norah KEATING. 2016. "Social Exclusion of Older Persons: A Scoping Review and Conceptual Framework." European Journal of Ageing 14(1): 81-98.

WANG, Chao, Mohammed A. QUDDUS, Marcus P. ENOCH, Tim RYLEY and Lisa DAVISON. 2015. "Exploring the Propensity to Travel by Demand Responsive Transport in the Rural Area of Lincolnshire in England." Case Studies on Transport Policy 3(2): 129-136.

WARD, Kim, Karen J. HOARE and Merryn GOTT. 2015. "Evolving from a Positivist to Constructionist Epistemology While Using Grounded Theory: Reflections of a Novice Researcher." Journal of Research in Nursing 20(6): 449-462.

WHISTON, Susan C., Rachel P. FELDWISCH, Kelsee M. EVANS, Chelsea S. BLACKMAN and Lynn GILMAN. 2015. “Older Professional Women's Views on Work: A Qualitative Analysis.” The Career Development Quarterly 63(2): 98-112.

WIGGS, Carol M. 2010. “Creating the Self: Exploring the Life Journey of Late Midlife Women.” Journal of Women and Aging 22(3): 218-233.

WOODSPRING, Naomi. 2016. Baby Boomers: Time and Ageing Bodies Bristol, UK: Policy Press.

\section{Author}

Alison Herbert is a Research Affiliate of the Irish Centre for Social Gerontology (ICSG), NUI Galway. Her doctoral thesis explored perspectives on ageing amongst mid-life women in Connemara, a rural region in the West of Ireland. ICSG is a multi-disciplinary research centre on ageing that develops and promotes social and economic aspects of ageing. Its focus is on research, education and training in the field of social gerontology in Ireland and internationally.

Contact: alison.herbert@nuigalway.ie 